\title{
The effects of hypoxia on active ionic transport processes in the gill epithelium of hyperregulating crab, Carcinus maneas
}

\author{
Čedomil Lucu ${ }^{\mathrm{a}, \mathrm{b}, *}$, Andreas Ziegler ${ }^{\mathrm{c}}$ \\ a Alfred Wegener-Institute Helmholtz Center for Polar and Marine Research Wadden Sea Station/List/Sylt, Germany \\ b Institute Ruđer Bošković, Center for Marine Research Rovinj, Zagreb, Croatia \\ ${ }^{c}$ Central Facility for Electron Microscopy University of Ulm, A. Einstein Alee 11, 89069 Ulm, Germany
}

\section{A R T I C L E I N F O}

\section{Keywords:}

Carcinus gill epithelium

Hypoxia

Short-circuit current

Morphometric analysis

Mitochondria

\begin{abstract}
A B S T R A C T
Effects of hypoxia on the osmorespiratory functions of the posterior gills of the shore crab Carcinus maenas acclimated to $12 \mathrm{ppt}$ seawater (DSW) were studied. Short-circuit current (Isc) across the hemilamella (one epithelium layer supported by cuticle) was substantially reduced under exposure to $1.6,2.0$, or $2.5 \mathrm{mg} \mathrm{O}_{2} / \mathrm{L}$ hypoxic saline (both sides of epithelium) and fully recovered after reoxygenation. Isc was reduced equally in the epithelium exposed to $1.6 \mathrm{mg} \mathrm{O}_{2} / \mathrm{L}$ on both sides and when the apical side was oxygenated and the basolateral side solely exposed to hypoxia. Under $1.6 \mathrm{mg} \mathrm{O}_{2} / \mathrm{L}$, at the level of maximum inhibition of Isc, conductance was decreased from $40.0 \mathrm{mS} \mathrm{cm}^{-2}$ to $34.7 \mathrm{mS} \mathrm{cm}^{-2}$ and fully recovered after reoxygenation. Isc inhibition under hypoxia and reduced ${ }^{86} \mathrm{Rb}^{+}\left(\mathrm{K}^{+}\right)$fluxes across apically located $\mathrm{K}^{+}$channels were caused preferentially by reversible inhibition of basolaterally located and ouabain sensitive $\mathrm{Na}^{+}, \mathrm{K}^{+}$-ATPase mediated electrogenic transport. Reversible inhibition of Isc is discussed as decline in active transport energy supply down regulating metabolic processes and saving energy during oxygen deprivation.

In response to a 4 day exposure of Carcinus to $2.0 \mathrm{mg} \mathrm{O}_{2} / \mathrm{L}$, hemolymph $\mathrm{Na}^{+}$and $\mathrm{Cl}^{-}$concentration decreased, i.e. hyperosmoregulation was weakened. Variations of the oxygen concentration level and exposure time to hypoxia lead to an increase of the surface of mitochondria per epithelium area and might in part compensate for the decrease in oxygen availability under hypoxic conditions.
\end{abstract}

\section{Introduction}

The shore crab Carcinus maenas Linnaeus, 1758 and its congener Carcinus aestuarii Nardo, 1847 are cosmopolitan species and two of the most successful invaders in shores of the world's oceans and seas (Darling et al., 2008). The crab Carcinus maenas is a typical inhabitant of coastal and estuarine zones where stress is associated with eutrophication and hypoxia (Weis, 2014).The shore crabs are known for high tolerance to fluctuations of environmental factors i.e., salinities (Siebers et al., 1982; Henry et al., 2002), temperatures (Cohen et al., 1995), and oxygen content in seawater (Taylor et al., 1977). Besides other factors, eutrophication and pollution are the most severe causes of hypoxia, with damaging consequences to aquatic organisms (Gray et al., 2002; Diaz and Rosenberg, 2008). Given the fact that Carcinus commonly lives in estuarine habitats, one might expect that they have evolved tissue-specific mechanisms for coping with exposure to environmental hypoxia. Studies of hypoxia at the organismic, tissue and cellular levels are needed to assess the effects of hypoxia on organisms. The gills of Crustacea form an interface between internal milieu and their environment and play a key osmorespiratory role. As a multifunctional organ they serve in: gas exchange (Burnett and Stickle, 2001), osmolyte transport, acid base and volume regulation (Gilles and Péqueux, 1985; Henry et al., 2002, 2003; Weihrauch et al., 2002; Fehsenfeld et al., 2011), immune functions (Burnett and Burnett, 2015) and detoxification (Ahearn et al., 2004).

Carcinus maenas is an osmoconformer in sea water. Under this condition the anterior and posterior gills are highly permeable as required for efficient gas exchange. In DSW (dilute seawater) Carcinus is a hyperosmoregulator, their hemolymph osmolarity is about $300 \mathrm{mosmol} / \mathrm{L}$ higher then osmolarity in 10 ppt DSW (Pequeux, 1995; Lucu and Flik, 1999). In particular, during environmental changes, the animals change gill morphology in a way that multifunctional processes occur at an optimal level. In most of the hyperosmoregulating crabs, the anterior gill lamellae still function primarily in respiration. Thus, the thin epithelium of pavement cells does not change noticeably when crabs are acclimated to DSW (Pequeux et al., 1988; Compere et al., 1989). However, the ultrastructure of the posterior Carcinus gills change considerably after acclimation to low salinity. These changes

\footnotetext{
* Corresponding author at: Institute Ruđer Bošković, Center for Marine Research, 52210 Rovinj. G. Paliaga 5, Croatia.

E-mail address: lucu@irb.hr (Č. Lucu).
} 
include an increase in the length of the apical infoldings leading to the development of deep subcuticular channels, thicker gill ionocyte cells due to lengthening of basolateral interdigitations and an increase in number of mitochondria within basal infoldings (Compere et al., 1989; Pequeux, 1995; Freire et al., 2008). Furthermore, a substantial increase in oxygen consumption (Piller et al., 1985; Lucu and Pavičić, 1985) in the posterior gills of the crabs Callinectes and Carcinus after acclimation to $10-20$ ppt DSW indicate an increased gill metabolism. Thus, in these crabs acclimated in DSW activity of $\mathrm{Na}^{+}, \mathrm{K}^{+}$-ATPase is increased in posterior gills specialized for active ion uptake (Towle et al., 1976; Holliday, 1985; Lucu and Flik, 1999; Lovett et al., 2007; Tsai and Lin, 2007; Henry et al., 2012). Increased diffusion distance may reduce the ability to take up oxygen and reduce loss of ions from the hemolymph and thus the cost of ion regulation. These adaptive changes in gills during acclimation of Carcinus in DSW can be regarded as an example of an osmorespiratory compromise. A phenomenon, describing the balance between "need of oxygen" and "need of osmotic regulation" (Nilsson, 1986).

Most of the transport mechanisms of inorganic osmolytes in crustacean gills have been verified by application of perfusion and shortcircuit current methods (Henry et al., 2012). The short-circuit current (Isc) represents the rate of active transport across an epithelium bathed on both sides in equal saline and is one of the most powerful methods to measure transepithelial ion transport across a variety of epithelial membranes (Larsen, 2002; Li et al., 2004). The introduction of the short-circuit current method by Hans Ussing in 1955, initiated a novel way to study ion transport across epithelial membranes. The method was applied on numerous mammals epithelia (Clarke, 2009; Hug and Tuemmler, 2004) and fish intestine (Marshall and Grossel, 2005).

Application of the electrophysiological Isc method in transport studies on Carcinus gill hemilamella has shown that inward movement of $\mathrm{Cl}^{-}$is mediated by $\mathrm{Na}^{+} / \mathrm{K}^{+} / 2 \mathrm{Cl}^{-}$cotransport (Riestenpatt et al., 1996; Onken et al., 2003; Lucu and Towle, 2010). The main generator of this coupled transport is the basolaterally located $\mathrm{Na}^{+}, \mathrm{K}^{+}$-ATPase, because specific inhibition of $\mathrm{Na}^{+}, \mathrm{K}^{+}$-ATPase by applying ouabain to the basolateral side of the posterior Carcinus gills inhibits the Isc (Siebers et al., 1985; Onken and Siebers, 1992; Riestenpatt et al., 1996; Lucu and Flik, 1999).

The objective of this study was to determine how hypoxia is associated with electrogenic transport disturbance in the posterior gill preparation isolated from hypoxia-tolerant shore crab Carcinus. One of the most fundamental processes for all cells is the maintenance of a high, intracellular content of ATP. Indeed, almost all energy-requiring processes in cells are driven, either directly or indirectly, by hydrolysis of ATP. Differential regulation of ATP in mitochondria and metabolic priorities for $\mathrm{Na}^{+}, \mathrm{K}^{+}$-ATPase activities depends on tissue oxygenation (Petrushanko et al., 2007).

By using the short-circuit current method we studied the effect of hypoxia on active electrogenic Isc across the hemilamella isolated from posterior gills of the crab acclimated to DSW. Our study is focused particularly on the basolateral side where ouabain-sensitive $\mathrm{Na}^{+}, \mathrm{K}^{+}$ATPase is located. In addition, the effect of hypoxia on ${ }^{86} \mathrm{Rb}\left(\mathrm{K}^{+}\right)$ fluxes, which reflects at least partially the turnover of $\mathrm{K}^{+}$by the $\mathrm{Na}^{+}$/ $\mathrm{K}^{+}$pump, was studied. By varying duration and exposure of $\mathrm{O}_{2}$ saturation in the hemilamella, we tested viability of the epithelium to acute hypoxia. Reversible block of Isc in the present study suggests a modification in which energy consuming processes are down regulated during hypoxia (Boutilier, 2001). Since the crustacean gill has been characterized as a leaky epithelium (Onken and Riestenpatt, 1998)), with a relatively high ionic permeability, we also studied the effect of hypoxia on electrical conductance, across the epithelium.

Oxygen limitation is generally considered an impairment of mitochondrial respiration and thus ATP synthesis. Therefore, we examined if the volume and surface area of mitochondria change when the posterior gill cells of the crab are exposed to hypoxia. To our knowledge this is the first study to report on the effects of hypoxia on active ion transport in a crustacean isolated gill epithelium.

\section{Material and methods}

\subsection{Animal, exposure}

Shore crabs, Carcinus maenas weighing 30-50 g, were collected from the North Sea coast of Westerland (Sylt) in the period September-November 2015, and only intermoult male crabs were used. Before the experiments, crabs were fed 2 times weekly with chopped bovine heart meat. Crabs were kept in aquaria with an open circuit of seawater (Institute Alfred Wegener, Sylt). Crabs were acclimated for at least three weeks in $12 \mathrm{ppt}$ dilute seawater (DSW) prepared by diluting natural seawater with deionized water. The animals were kept in aerated aquaria at $15{ }^{\circ} \mathrm{C}$ and under natural light condition. The dissolved oxygen concentration in normoxic DSW was controlled daily and ranged from 8 to $9 \mathrm{mg} / \mathrm{L}$.

The oxygen level was reduced by bubbling nitrogen to obtain the desired oxygen saturation. DSW was flowing through an open aeration column supplied with polypropylene spheres and then through a column where nitrogen flow was adjusted to maintain the oxygen level on the set point. An oxygen controller actuated the valves connecting to the nitrogen gas tank and air pump to maintain the desired oxygen level by delivering either nitrogen or air into the experimental tank (Bennett and Beitinger, 1995). Oxygen content in DSW and incubation medium was measured by an oximeter with automatic calibration (accuracy 0.5\% of value; Oxytester, WTW ProfiLine Oxy 1970, Germany).

\subsection{Electrophysiological studies}

After destroying the ventral ganglion, the carapace was lifted and then posterior pairs of gills were cut at the base by scissors and removed. We choose the 7th or 8th posterior gill for our studies because previous studies on Carcinus and some other Crustacea have measured significantly higher specific activities of the $\mathrm{Na}^{+}, \mathrm{K}^{+}$-ATPase in these gills than in anterior gills, leading to the suggestion that the posterior gills are mostly specialized for osmoregulation (Neufeld et al., 1980; Siebers et al., 1985).

Short circuit-current (Isc) and conductance (G) were measured in the gill epithelia as described by Onken and Siebers, 1992; Lucu and Flik, 1999. Hemilamella consisting of a single epithelial layer supported by an apical layer of cuticle were prepared by splitting the gill lamella in half longitudinally. Hemilamella isolated from crabs acclimated in normoxic DSW were used for measuring effects of hypoxia on Isc. This preparation was mounted in a modified Ussing micro-chamber with a circular aperture of $1.25 \mathrm{~mm}$ in diameter. The epithelium was positioned onto the aperture, which rim area was slightly greased to minimize edge damage. The criterion for the validity of the preparation was a stable Isc (for $>3 \mathrm{~h}$ ) when control physiological saline was applied. The electrical parameters of this preparation were measured using an automatic voltage clamp 558C-5 amplifier (Bioengineering, The University of Iowa, USA). The transepithelial potential was controlled by mercury reference electrodes (Broadley James Corporation; USA). Voltage pulses of $1.0 \mathrm{mV}$ (duration $1 \mathrm{~s} ; 500 \mathrm{~s}$. interval between pulses) were applied by a pulse generator to measure epithelial conductance. The outputs from the voltage clamp were visualized using a pen recorder (Linseis Ly 17100). The total resistance measured by voltage pulses was corrected for chamber resistance by subtracting the resistance measured in the saline filled chamber after the installed tissue had been pierced with a needle on completion of each experiment. The measured current across the hemilamella was corrected for each preparation following Ohm's law. In the hypoxia experiments apical and basolateral sides were perfused with identical crab saline, which were circulated by a two-channel Watson-Marlow peristaltic pump (Sci 400) at a flow rate of $0.5 \mathrm{ml} / \mathrm{min}$. The crab saline contained (in $\mathrm{mM}$ ) to: $\mathrm{NaCl}, 235 ; \mathrm{KCl}, 5 ; \mathrm{MgCl}_{2}, 4.0 ; \mathrm{CaCl}_{2} 2.2 ; \mathrm{NaHCO}_{3}, 6$; 
glucose, 10; HEPES, 10. pH of 7.6 was adjusted by TRIS base (see Lucu and Flik, 1999). Perfusion saline was bubbled with compressed air and $\mathrm{N}_{2}$ gas to reach the desired $\mathrm{O}_{2}$ concentration at both sides of epithelia. The $\mathrm{O}_{2}$ concentration was measured by an oximeter, which electrode was immersed in the perfusion saline during an experiment. Oxygen content in normoxic saline ranged from 8.5 to $9.5 \mathrm{mg} \mathrm{O} / 2 / \mathrm{L}$ and $\mathrm{pH}$ values in the normoxic and groups exposed to hypoxia was $7.7 \pm 0.2$.

\section{3. ${ }^{86} \mathrm{Rb}$ fluxes}

Radioactive isotope ${ }^{86} \mathrm{RbCl}$ in aqueous solution of $56.5 \mathrm{MBq} / \mathrm{ml}$ was purchased from Perkin Elmer (USA). $10 \mathrm{ml}$ saline containing 0.14 MBq of ${ }^{86} \mathrm{Rb}$ solution was recirculated in one half-chamber (hot side). On the other side of the half-chamber fresh and initially non- radioactive saline was pumped under open-circuit condition. The isotope was added either basolaterally or apically to measure the efflux or influx, respectively. Saline was circulated at an equal rate $(0.5 \mathrm{ml} / \mathrm{min})$, and the levels of saline in the hemichambers were kept equal to avoid any pressure difference. Fluxes were studied by fully aerated saline and consecutively under hypoxic condition $(1.6 \mathrm{mg} \mathrm{O} / \mathrm{L})$ at both sides of the epithelium. After 10, 20 and $30 \mathrm{~min}$ of incubation with ${ }^{86} \mathrm{RbCl}$, $10 \mathrm{ml}$ of initially nonradioactive solution was collected. From this portion $1 \mathrm{ml}$ of solution was sampled for scintillation measurements. From the hot side, where initial radioactivity was added, samples of $20 \mu \mathrm{L}$ were collected at the same time intervals and diluted with $1 \mathrm{ml}$ nonradioactive saline. Probes were mixed with $3 \mathrm{ml}$ scintillation cocktail (HiSafe OptiPhase, Packard Insta gel), and counted by a liquid scintillation counter (Beckman, Turku, Finland). During the ${ }^{86} \mathrm{Rb}$ flux experiments Isc was recorded simultaneously. Separate preparations were used for rubidium influx $\left(\mathrm{J}_{\mathrm{A}^{-}}>_{\mathrm{B}}\right)$ and efflux $\left(\mathrm{J}_{\mathrm{B}^{-}}>_{\mathrm{A}}\right)$ determinations ( $\mathrm{A}=$ apical and $\mathrm{B}=$ basolateral side). Radioactivity passing the hemilamella preparation from the perfusion saline at one side of the epithelium to the saline at the opposite side was used to measure fluxes expressed in $\mu \mathrm{mol} \mathrm{cm}^{-2} \mathrm{~h}^{-1}$.

\section{4. $\mathrm{Na}^{+}, \mathrm{Cl}^{-}$and $\mathrm{Ca}^{2+}$ determinations}

$\mathrm{Na}^{+}$concentration of the hemolymph was determined by flame photometric measurements and concentrations of $\mathrm{Cl}^{-}$as determined with a coulometric CMT 10 Chloride titrator (Radiometer, Copenhagen). $\mathrm{Ca}^{2+}$ concentration was measured with an ion-selective electrode ELIT 8041 with PVC membrane (Harrow,U.K).

\subsection{Preparation of samples for TEM (transmission electron microscopy) and morphometric analysis of mitochondria}

One mm wide strips of posterior gill lamella were cut using razor blades. The samples were fixed in a solution containing $4 \%$ paraformaldehyde, $5 \%$ glutaraldehyde, $0.05 \% \mathrm{CaCl}_{2}$ and $15 \%$ saccharose in $0.1 \mathrm{~mol} / \mathrm{L}$ Na-cacodylate buffer $(\mathrm{pH} 7.4)$ overnight at $4{ }^{\circ} \mathrm{C}$, washed once for 10 min in Na-cacodylate (pH 7.4) containing 15\% saccharose and 3 times in the buffer without saccharose. Samples were then postfixed in $1 \% \mathrm{OsO}_{4}+0.8 \% \mathrm{~K}_{3} \mathrm{Fe}(\mathrm{CN})_{6}$ in $0.1 \mathrm{~mol} / \mathrm{L} \mathrm{Na}$-cacodylate ( $\mathrm{pH} 7.4$ ), dehydrated in a series of isopropanol, block contrasted in uranyl acetate in ethanol, washed 3 times in ethanol and two times in propylene oxide, and embedded in Epon resin. Ultrathin $(70 \mathrm{~nm})$ cross sections through the lamella were cut with a diamond knife (Diatome) on a Leica Ultracut LCT Ultramicrotome. Sections were mounted on carbon-coated Formvar films on $1 \mathrm{~mm}$ diameter single hole copper EM grids (Plano, Wetzlar, Germany) stained with $0.3 \%$ lead citrate and viewed with a Zeiss 912 TEM (Germany) equipped with an omega energy filter using the electrically scattered electrons of the zero-loss peak. Digital micrographs were recorded with a $2 \mathrm{k} \times 2 \mathrm{k}$ pixel camera (TRS, Moorenweis, Germany) using TRS software. Series of up to $98(14 \times 7)$ micrographs of the sample, at a magnification of 6300 times each, were mounted together and stitched using the TRS software. That way we obtained very large images covering the whole width of the lamella. These images were used for the morphometric analysis. We used three control animals and one animal from each of the three treatments described in chapter 2.1 .

The method of Merz (1967) was employed to determine the surface to volume ratio of the mitochondria, and the total surface and volume of mitochondria per $\mu \mathrm{m}^{2}$ of the epithelium. Using GNU Image Manipulation Program (GIMP) images were overlaid with a test system of coherent semicircular lines and regular point arrays. Test areas covered the whole height of the epithelial cells along a length ' $\mathrm{e}$ ' of the epithelium (Ziegler and Merz, 1999). The profile length Lm of all mitochondria within the test field was determined by

$\mathrm{Lm}=\mathrm{Nd}(\mu \mathrm{m})$

with ' $\mathrm{N}$ ' as the number of intersections of the semicircular lines with the outer membrane of the mitochondria and ' $\mathrm{d}$ ' as the diameter of the semicircles. Lm was normalized to a standard length of $1 \mu \mathrm{m}$ by

$\mathrm{L}=\mathrm{Lm} / \mathrm{e}(\mu \mathrm{m})$

with ' $\mathrm{L}$ ' as the standardized profile length and ' $\mathrm{e}$ ' the length of the test area. The total surfaces 'As'of the mitochondria per $\mu \mathrm{m}^{2}$ of the epithelium were determined by

As $=\mathrm{L} \times 1.273\left(\mu \mathrm{m}^{2} / \mu \mathrm{m}^{2}\right)$.

The volume density of mitochondria 'Vm'per $\mu \mathrm{m}^{2}$ of the epithelium was calculated from the profile area of mitochondria 'Am' along the length ' $\mathrm{e}$ ' of the test area. ' $\mathrm{Vm}^{\prime}={ }^{\prime}$ Am' was determined using the regular point arrays by counting the number of points on the mitochondria 'Pm' within the test area, and normalized to a standard surface of epithelium of $1 \mu \mathrm{m}^{2}$ by

$\mathrm{Vm}=\operatorname{Pmd} 2 / \mathrm{e}\left(\mu \mathrm{m}^{3} / \mu \mathrm{m}^{2}\right)$.

One way ANOVA was used to detect significant differences in the As/Vm ratio, and the surface and volume per $\mu m^{2}$ of epithelium between treated and untreated gills. Holm-Sidak's multiple comparisons tests were used to assign significant differences between hypoxic and the normoxic treatments.

\section{Results}

\subsection{Effect of hypoxia on Isc, conductance and ${ }^{86} R b^{+}\left(K^{+}\right)$fluxes}

In the first set of exposures we tested the effect of $2.5 \mathrm{mg} \mathrm{O} / \mathrm{L}$ (5.5 kPa; 41.6 Torr) on Isc across the isolated hemilamella. Isc represents a negative charge flow from the apical to the basolateral side of the preparation. Under hypoxic condition at both sides of the epithelium, Isc was reduced by $69 \%$ and kept at new steady-state for $20 \mathrm{~min}$. Reoxygenation recovered the Isc (Fig. 1a).

At an oxygen concentration of $2.0 \mathrm{mg} \mathrm{O} / \mathrm{L}$ ( $4.4 \mathrm{kPa}$; $33.2 \mathrm{Torr}$; both sides of epithelium), Isc was reduced from normoxia by $38 \%$ and at this level a steady-state was kept for $25 \mathrm{~min}$. After lowering the oxygen concentration to $1.6 \mathrm{mg} \mathrm{O} / 2 / \mathrm{L}(3.6 \mathrm{kPa} ; 26.6$ Torr) Isc was reduced further to a value of $-8.7 \pm 7.5 \mu \mathrm{A} \mathrm{cm} \mathrm{cm}^{-2}(N=5)$. After applying normoxic conditions the Isc almost fully recovered within about $50 \mathrm{~min}$ (Fig. 1b).

During basolaterally induced hypoxia $(1.6 \mathrm{mg} \mathrm{O} / 2$; apical side was aerated - normoxia) Isc was reduced by $98 \%$. Isc was fully recovered after normoxia (Fig. 1c).

Hypoxia at $1.6 \mathrm{mg} \mathrm{O} / 2$ on both sides of the epithelium over $130 \mathrm{~min}$ reduced Isc by $98 \%$ to $-6.1 \pm 8.2 \mu \mathrm{A} \mathrm{cm} \mathrm{cm}^{-2}(N=5)$ and after reoxygenation Isc again fully recovered (Fig. 1d).

No differences were noticed in the inhibitory effects on Isc between a combination of ouabain $(1.0 \mathrm{mM})$ and hypoxia $\left(1.6 \mathrm{mg} \mathrm{O}_{2} / \mathrm{L}\right)$ and single ouabain treatment i.e. ouabain reversible blocks Isc close to the zero value (Fig. 2). Upon severe hypoxia of $1.6 \mathrm{mg} \mathrm{O} / \mathrm{L}$ (both sides of epithelium) kept for $100 \mathrm{~min}$, when Isc dropped almost to zero, 
a
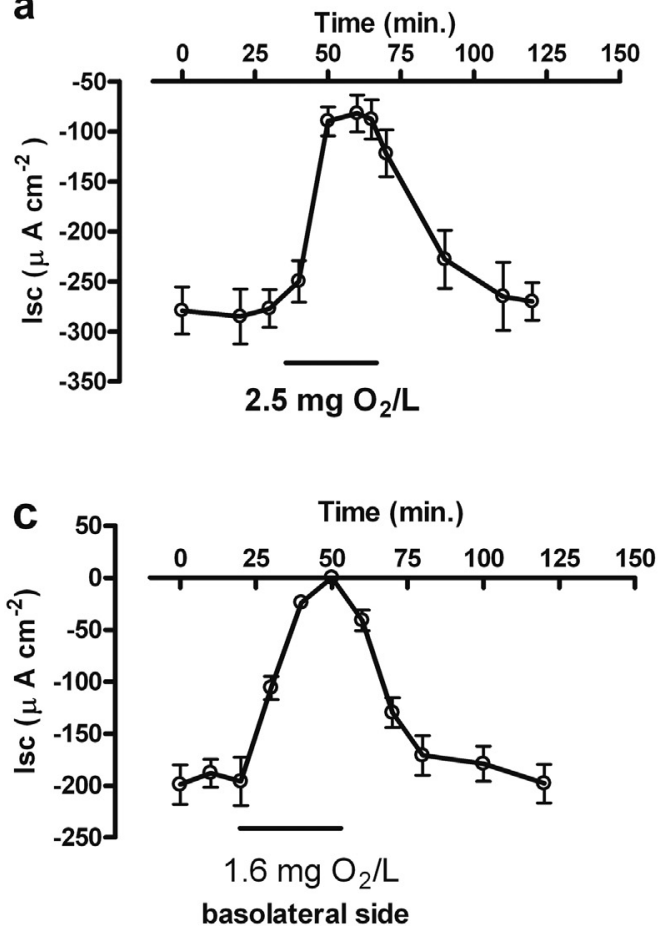

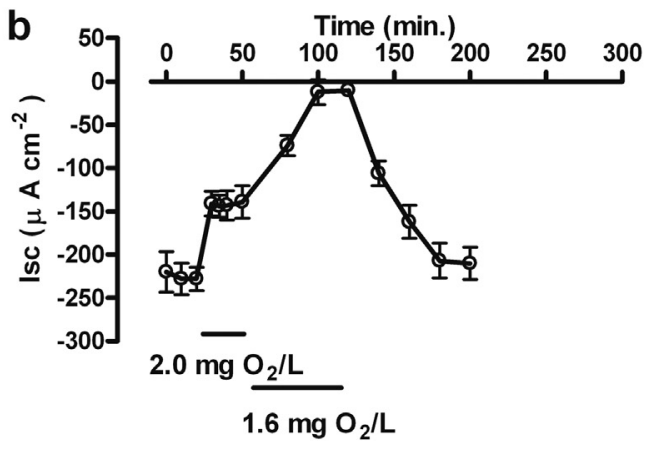

d

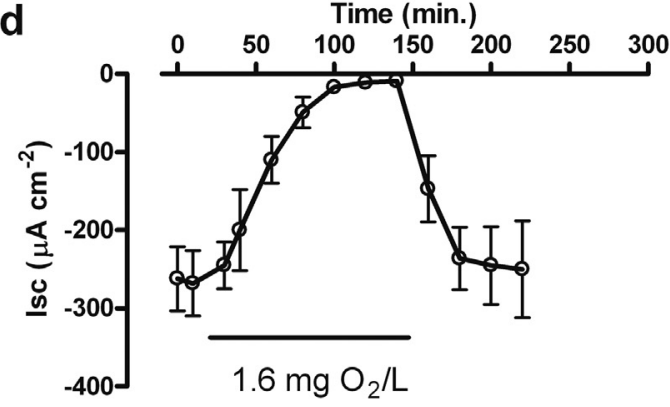

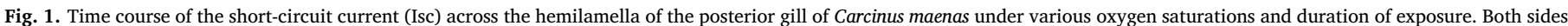

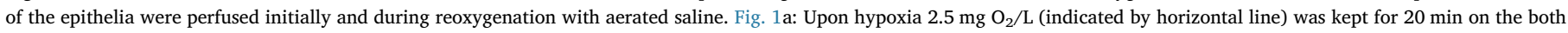

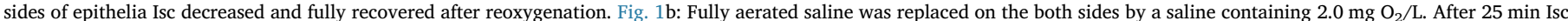

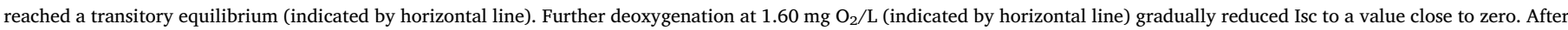

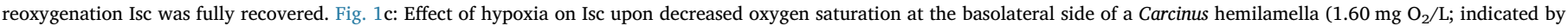

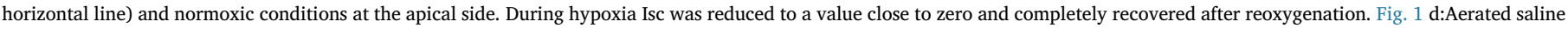

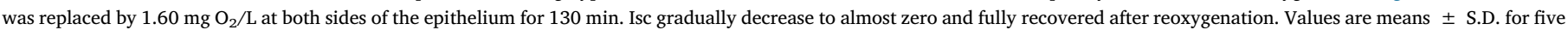
individual samples.

conductance was significantly decreased from $40.0 \pm 1.8 \mathrm{mS} \mathrm{cm} \mathrm{cm}^{-2}$ (normoxia) to the value of $34.7 \pm 2.3 \mathrm{mS} \mathrm{cm}^{-2}$ ( $P<0.05$; hypoxia). Conductance of the gill hemilamella after exposure to $1 \mathrm{mM}$ ouabain was not significantly different from the normoxic group (Fig. 3).

$\mathrm{K}^{+}$fluxes across Carcinus gill hemilamella were studied in an Ussing's type chamber using ${ }^{86} \mathrm{RbCl}$ as a tracer (Fig. 4). Unidirectional ion fluxes were determined from the content of ${ }^{86} \mathrm{Rb}$ on the side opposite to which it was added. Under hypoxic conditions at both sides of the epithelium ${ }^{86} \mathrm{Rb}^{+}\left(\mathrm{K}^{+}\right)$efflux $\left(\mathrm{J}_{\mathrm{B} \rightarrow \mathrm{A} ;} ; \quad \mathrm{B}=\right.$ basolateral side; $\mathrm{A}=$ apical side) requires an "extracellular" uptake across the basolateral epithelial side into the cells and efflux (by convention negative) at the apical-cuticular side. Upon hypoxic conditions of $1.6 \mathrm{mg} \mathrm{O}_{2} / \mathrm{L}$ at both sides of the epithelium, Isc was reduced to almost zero and efflux of ${ }^{86} \mathrm{Rb}$ was changed from $1.59 \pm 0.06 \mu \mathrm{mol} \mathrm{cm}{ }^{-2} \mathrm{~h}^{-1}$ (normoxic condition) to $0.86 \pm 0.05 \mu \mathrm{mol} \mathrm{cm} \mathrm{cm}^{-2} \mathrm{~h}^{-1}$ (hypoxia; $P<0.001$ ). In contrast, the influx $\left(\mathrm{J}_{\mathrm{A}} \rightarrow{ }_{\mathrm{B}}\right)$ was slightly and not significantly increased under hypoxic conditions $(P>0.05)$. The net ${ }^{86} \mathrm{Rb}^{+}\left(\mathrm{K}^{+}\right)$fluxes, in the direction from the basolateral to the apical side $(0.67 \pm 0.08 \mu \mathrm{mol}$ $\mathrm{cm}^{-2} \mathrm{~h}^{-1}$ under normoxic condition), were blocked to almost zero under hypoxia $\left(0.18 \pm 0.09 \mu \mathrm{mol} \mathrm{cm}^{-2} \mathrm{~h}^{-1} ; P<0.001\right)$. Reoxygenation (normoxia after) recovered Isc and ${ }^{86} \mathrm{Rb}$ fluxes. There is no significant difference between normoxic fluxes before (normoxia before) and after (normoxia after) hypoxia $(P>0.05)$ (Fig. 4).

\subsection{Hemolymph concentration and morphometric analysis of mitochondria under hypoxia}

When crabs are acclimated to DSW, the hemolymph ion concentrations was studied and a morphometric analyses of mitochondria in the posterior gills of the crabs under hypoxia was performed.

After 4 days of hypoxia at $2.5 \mathrm{mg} \mathrm{O} / 2 / \mathrm{L}(5.6 \mathrm{kPa}$; 42.6 Torr $)$ the concentration of sodium and chloride in the hemolymph were significantly lower than in animals of the control normoxic groups. Ionic calcium concentration was not different between normoxic and hypoxic conditions (Table 1).

There were no obvious differences between the ultrastructure of gill epithelia kept under normoxia (Fig. 5a) and those kept under the various hypoxic conditions, except for a higher abundance of elongated -

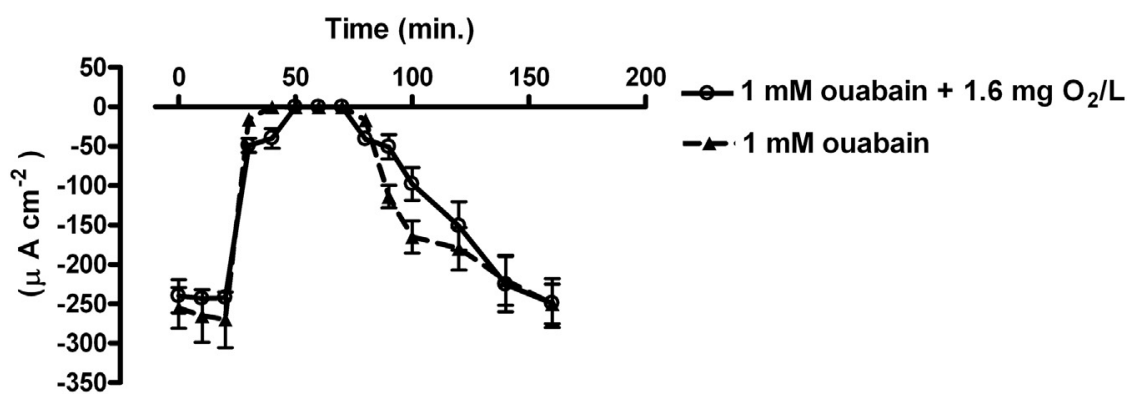

Fig. 2. $1.0 \mathrm{mM}$ ouabain in oxygenated saline at the basolateral side almost completely blocked Isc. After removal of ouabain Isc fully recovered. $1.0 \mathrm{mM}$ ouabain in combination with hypoxic saline ( $1.6 \mathrm{mg} \mathrm{O}_{2} / \mathrm{L}$ ) reduced Isc close to zero. Reoxygenation and removal of ouabain completely recovered Isc. Values are means \pm S.D. for five individual samples. 


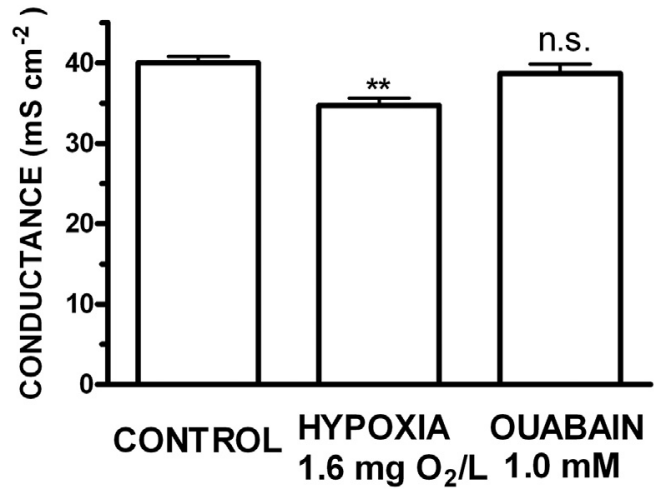

Fig. 3. Diagram showing the electrical conductance $\left(\mathrm{mS} \mathrm{cm}^{-2}\right)$ of the hemilamella isolated from posterior Carcinus gill. Conductance in the control group was compared with that of severe hypoxia $(1.60 \mathrm{mg} \mathrm{O} / \mathrm{L})$ and that treated with $1 \mathrm{mM}$ ouabain. Values are means \pm S.D. for five individual samples. A significant difference of conductance was found between the control group and that treatment with severe hypoxia $(* * P<0.01$ ). There was not significant difference in conductance between the control group and the group containing $1 \mathrm{mM}$ ouabain $(P>0.05)$.
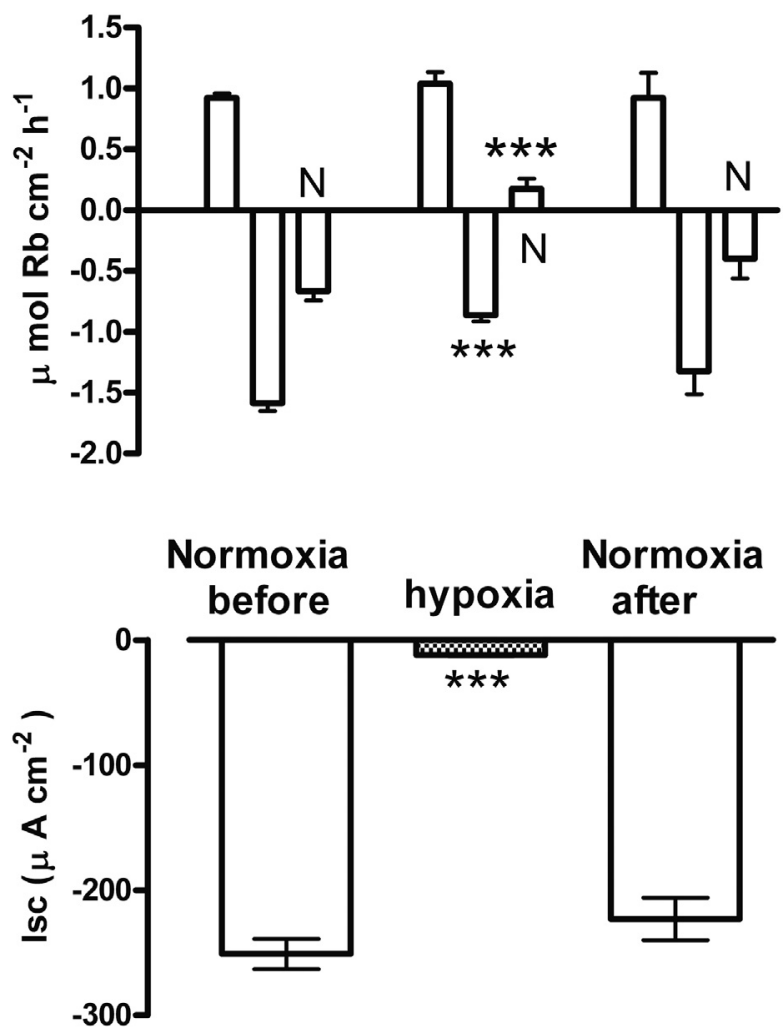

Fig. 4. Upper figure: Effect of hypoxia on ${ }^{86} \mathrm{Rb}(\mathrm{K})$ fluxes in short-circuited Carcinus gill hemilamella ${ }^{86} \mathrm{Rb}$ influxes (upward bars; by convention positive) from the apical to the basolateral side and effluxes (downward bars; by convention negative) from the basolateral to the apical side were measured. Net fluxes $(\mathrm{N})$ were obtained by subtracting the efflux from the influx. Fluxes were studied successively in fully aerated saline (normoxia before), after incubation for $40 \mathrm{~min}$ in hypoxic saline containing $1.6 \mathrm{mg} \mathrm{O} / \mathrm{L}$ at both sides of epithelium (hypoxia) and after reoxygenation (normoxia after). The isotope was added either basolaterally or apically to measure the efflux or influx, respectively. Separate preparations were used for rubidium influx and efflux determinations. Values are means \pm S.E. for 6 individual samples. Two-way ANOVA followed by Bonferroni's multiple comparisons post hoc tests comparison tests (Graph Pad Prism software) was used to compare the influx, efflux and net flux under normoxia with those under hypoxic condition. Statistical analysis: fluxes normoxia before vs fluxes hypoxia; influx $(P>0.05)$ : effluxes $\left({ }^{* * *} P<0.001\right)$ and net fluxes $\left({ }^{* * *} P<0.001\right)$. Fluxes normoxia before vs fluxes normoxia after; influx $(P>0.05)$; efflux $(P>0.05)$ and net flux $(P>0.05)$. Lower figure: Simultaneous effects of hypoxia on Isc for normoxia before, hypoxia and normoxia after (reoxygenation). Error bars indicate means \pm S.D. for 4 individual samples. Normoxia before vs hypoxia, $* * *(P<0.001)$.
Table 1

Sodium, chloride and calcium (ionic) concentrations in the hemolymph under normoxic and hypoxic DSW (4 days $2.5 \mathrm{mg} \mathrm{O}_{2} / \mathrm{L}$ ) condition. Level of significance (Student's $t$-test) is presented. Values are means \pm S.E.; number of observations in parentheses.

\begin{tabular}{llll}
\hline & 12 ppt-normoxia & & 12 ppt hypoxia. \\
\hline $\mathrm{Na}^{+}, \mathrm{mmol} /$ & $320 \pm 10(6)$ & $P<0.001$ & $280 \pm 9(6)$. \\
$\mathrm{Cl}^{-}, \mathrm{mmol} / \mathrm{L}$ & $325 \pm 12(6)$ & $P<0.001$ & $285 \pm 10(6)$. \\
$\mathrm{Ca}^{2+}, \mathrm{mmol} / \mathrm{L}$ & $5.8 \pm 0.2(5)$ & $P>0.05$ & $5.0 \pm 0.4(5)$. \\
\hline
\end{tabular}
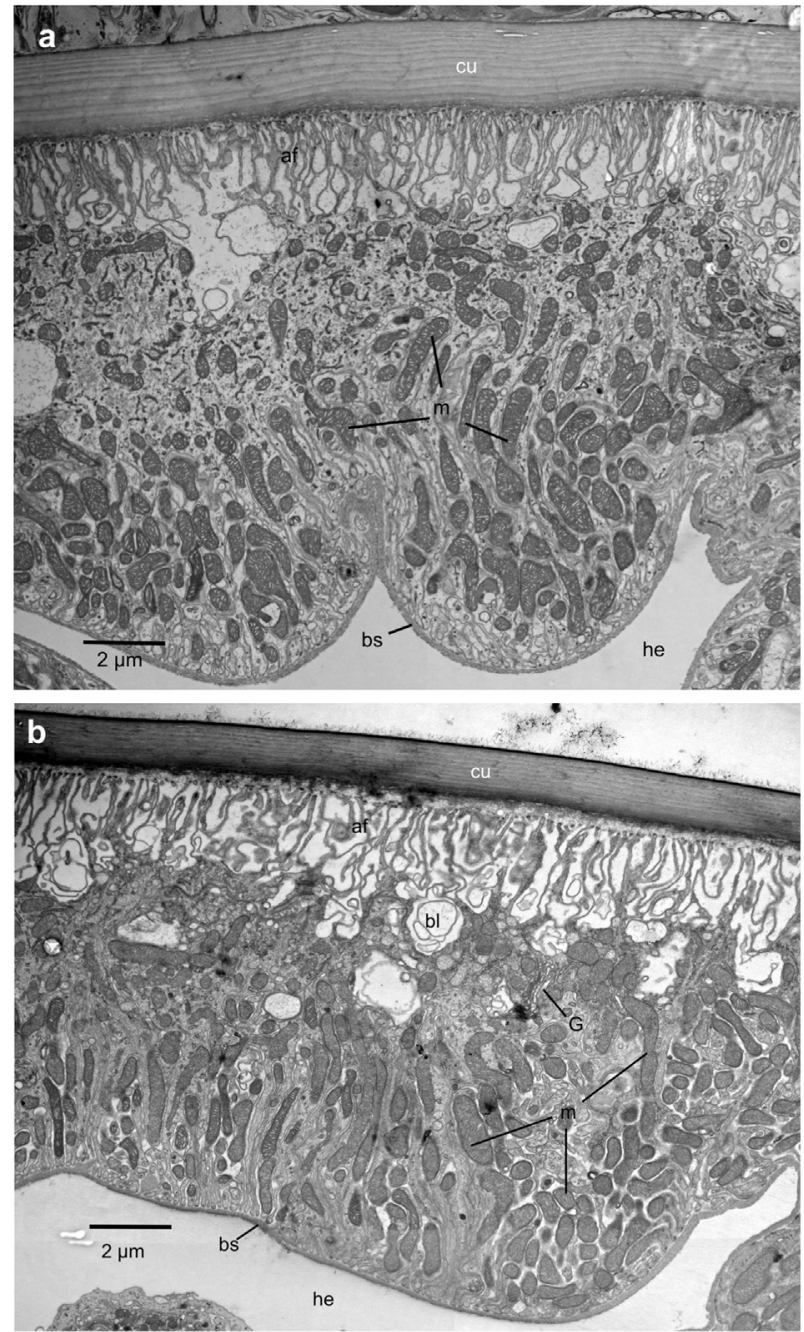

Fig. 5. Electron micrographs of the posterior gill epithelium of Carcinus maenas kept either, as a control, in DSW under normoxic conditions (a) or for 10 days at intermittent hypoxia at an oxygen concentration of $4.0 \mathrm{mg} \mathrm{O} / \mathrm{L}$ in DSW during night $(12 \mathrm{~h})$ and normoxia during the day (b). More elongated shaped profiles of mitochondria (m) are present upon hypoxia; af, apical folds; bl, bubble-like dilations of extracellular space; bs, basal lamina; cu, cuticle; G, Golgy apparatus; he, hemolymph space.

elliptically shaped profiles of mitochondria (Fig. 5b). We have also studied the effect of the various oxygen saturations and lengths of treatments on mitochondrion morphology in the posterior gill lamellae. Since the shape of mitochondrial profiles varies considerably within sections of the same epithelium a morphometric approach was mandatory. The morphometric analysis showed that in the gill lamella of all three crabs kept under hypoxia the surface to volume ratio (Fig. 6a) and the surface of mitochondria per $\mu \mathrm{m}^{2}$ of epithelium (Fig. 6b) was significantly higher in comparison to that in the control animals kept under normoxic conditions. In contrast the volume of mitochondria per $\mu^{2}$ of epithelium was not significantly different from the control (Fig. 6c). 
a

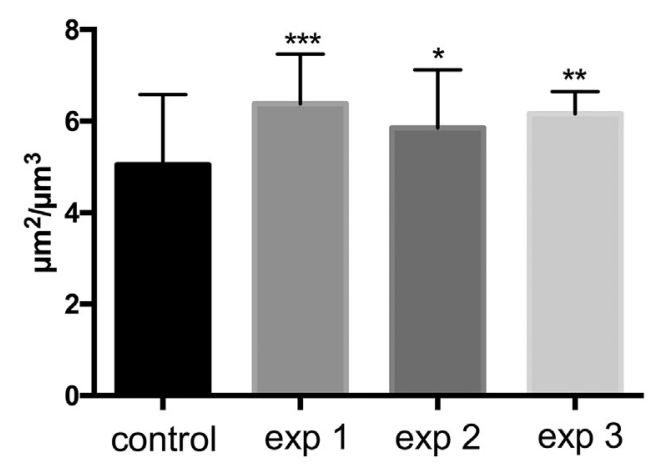

b
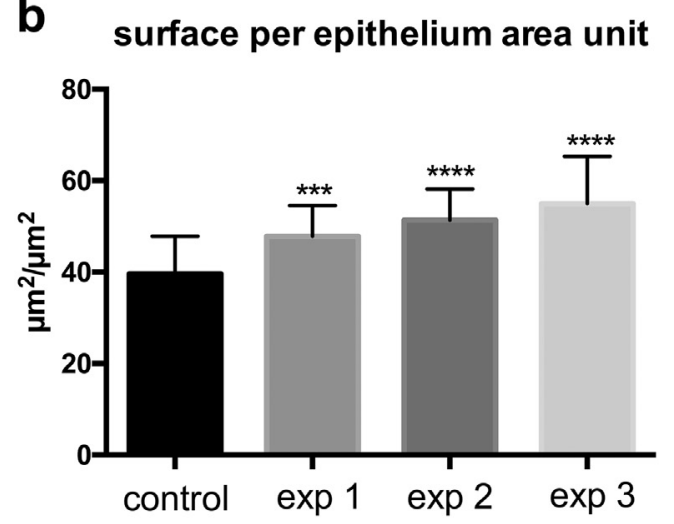

C volume per epithelium area unit

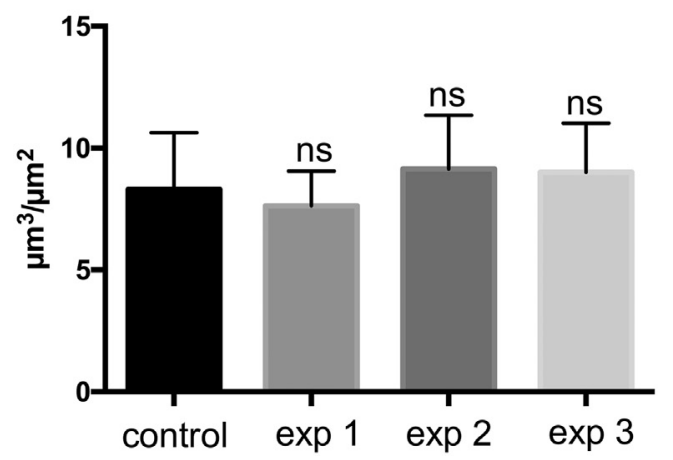

Fig. 6. Morphometric analysis of mitochondria in the posterior gill epithelium of Carcinus maenas kept in diluted seawater (DSW) under various oxygen saturations and durations of exposures. Surface/volume ratio of the mitochondria (a) and the surface per $\mu \mathrm{m} 2$ epithelium (b) were significantly increased in animals exposed to hypoxia in comparison to control animals kept under normoxic conditions. The volume of mitochondria per $\mu \mathrm{m}^{2}$ epithelium (c) was not significantly changed; exp. 1, $1.2 \mathrm{mg} \mathrm{O}_{2} / \mathrm{L}$ in DSW for $12 \mathrm{~h}$; exp. 2, $2.5 \mathrm{mg} \mathrm{O} / 2$ L during for 4 days; exp. 3, $4.0 \mathrm{mg} \mathrm{O} / 2$ in DSW for $12 \mathrm{~h}$ (night) and daily normoxia for 10 days. Number of test fields/animals were 48/3, 20/1, 15/1 and 15/1 in control, exp. 1, exp. 2, and exp. 3, respectively. ${ }^{*} P \leq 0.05$, $* * P \leq 0.01$, $* * * P \leq 0.001$, $* * * * P \leq 0.0001$, ns, not significant. Values are means \pm S.D.

\section{Discussion}

\subsection{Inhibition of Isc, $R b$ fluxes and conductance in gill epithelium by} hypoxia

The studies on the short-circuit current under hypoxia were undertaken using the thick region of the hemilamella epithelium of the posterior gills, close to the afferent blood vessel, where high density mitochondrion-rich ionocyte cells, involved in osmoregulatory processes are found (Pequeux et al., 1988; Compere et al., 1989). In this region of Carcinus gills, short-circuited active ion transport processes under normoxic condition have been studied by Onken and Siebers, 1992; Riestenpatt et al., 1996; Lucu and Flik, 1999. In the Carcinus hemilamella, Isc ion transport activity was inhibited under hypoxia at the basolateral side. It was shown that these epithelia mounted in Ussing type chamber under identical salines on the both sides of epithelium produced an inward negative Isc polarity (charge flow) directed from the apical to basolateral side. Inward negative Isc measured under these conditions is an indication of the presence of electrogenic ion transport mechanisms. High viability of the Carcinus epithelium is evidenced by the full recovery of the Isc upon reoxygenation after 20-130 min exposure to hypoxia. Our data are similar to those found in mammalian intestinal tissues. Short-circuit current and transepithelial potential (TEP) of the rat colon -mucosa and human colon are sensitive to acute hypoxia. Bilateral hypoxia reduces Isc and TEP by 50 to $70 \%$ and an overshoot was observed after reoxygenation (Saraví et al., 2003). Similarly, in the isolated human colonic mucosa, when hypoxia is either induced at both sides or only at the basolateral side of epithelia, Isc and transepithelial resistance were decreased (Carra et al., 2013). Similary, in the mucosa-submucosa from rat distal colon preparation mounted in Ussing type chamber, Isc and transepithelial resistance under hypoxia first transiently decreased, than increased and finally decreased below the initial baseline (Schindele et al., 2016).

${ }^{86} \mathrm{Rb}$ fluxes across hemilamella were studied as a measure of change of $\mathrm{K}^{+}$transport. A large fraction of $\mathrm{K}^{+}$is accumulated in the cells from the activity of the $\mathrm{Na}^{+} / \mathrm{K}^{+}$pump (Clausen, 2013). In the current study we found that, besides ouabain (normoxic condition), hypoxia reduced ${ }^{86} \mathrm{Rb}^{+}$effluxes from the basolateral to the apical side of the gill hemilamella, where ${ }^{86} \mathrm{Rb}\left(\mathrm{K}^{+}\right)$ions enter the cells by the activity of $\mathrm{Na}^{+}$, $\mathrm{K}^{+}$- ATPase, at the basolateral side. In the hyperosmoregulating Carcinus the $\mathrm{Na}^{+} / \mathrm{K}^{+}$-pump actively transports $\mathrm{K}^{+}$into the cytoplasm of the gill epithelial cells from which it passively diffuses out of the cell through $\mathrm{K}^{+}$channels at both sides of the epithelium (Kirschner, 2004). In the epipodite preparation of the lobster Homarus americanus branchial cavity, similar transport processes to the gill preparation show that ${ }^{86} \mathrm{Rb}$ effluxes $\left(\mathrm{J}_{\mathrm{B}} \rightarrow \mathrm{J}_{\mathrm{A}} ; \mathrm{B}=\right.$ basolateral, $\mathrm{A}=$ apical side of epithelia) but not influxes $\left(\mathrm{J}_{\mathrm{A}} \rightarrow \mathrm{J}_{\mathrm{B}}\right)$ were reduced and determined as $\mathrm{Na}^{+}, \mathrm{K}^{+}$- ATPase modulated $\mathrm{K}^{+}$channels under normoxic condition (Lucu and Towle, 2010). Electrogenic transport of the posterior gill hemilamella depends on oxidative metabolism. We suggest that inhibition of $\mathrm{Na}^{+}, \mathrm{K}^{+}$- ATPase dependent electrogenic Isc transport is the dominant factor underlying the collapse of Isc and net ${ }^{86} \mathrm{Rb}\left(\mathrm{K}^{+}\right)$fluxes under hypoxia. We confirm earlier results that the specific inhibitor of the $\mathrm{Na}^{+}, \mathrm{K}^{+}$- ATPase, ouabain, inhibits Isc at the basolateral side under normoxic condition (Onken and Siebers, 1992; Riestenpatt et al., 1996; Lucu and Flik, 1999). Oxygen supply from the basolateral side of hemilamella is necessary to sustain Isc transport activity. Recovery of the net ${ }^{86} \mathrm{Rb}\left(\mathrm{K}^{+}\right)$fluxes and Isc after reoxygenation is accomplished if hypoxia is short enough to prevent epithelium damage. High activity and abundance of $\mathrm{Na}^{+}, \mathrm{K}^{+}$- ATPase is distributed in Carcinus gills (Siebers et al., 1982). We suggest that reversible inhibition of Isc - active transport as well as $\mathrm{K}\left({ }^{86} \mathrm{Rb}\right)$ fluxes are cellular mechanisms, which suppress metabolism and ATP consumption upon hypoxia. There are a number of publications showing that adaptation to hypoxia at the cellular level is regulated by decreasing energy consuming processes (Boutilier, 2001). Hypoxia reduced the TEP by $10 \mathrm{mV}$ in seawater- and freshwater- acclimated killifish Fundulus heteroclitus and reversed immediately after return to normoxia (Wood and Grossel, 2015). In the freshwater fish Astronotus ocellatus $\mathrm{Na}^{+} \mathrm{K}^{+}$-ATPase activity was decreased and subsequently $\mathrm{Na}^{+}$uptake capacity reduced as a response to acute hypoxa. Upon reoxygenation $\mathrm{Na}^{+}$uptake was recovered. The low branchial paracellular permeability tested during swimming exercise may be an additional adaptive mechanism in limiting osmoregulatory cost under hypoxia (Wood et al., 2007; Robertson et al., 2015).

Hypoxia diminishes intracellular ATP production in the trout hepatocytes (Bogdanova et al., 2005). Invertebrate survival during 
hypoxia is made possible primarily by ATP conservation (Larade and Storey, 2009; Gorr et al., 2006). During this state the most energetically expensive cellular functions, such as the $\mathrm{Na}^{+} / \mathrm{K}^{+}$pump, are drastically suppressed,thereby reducing overall ATP consumption to match the concomitant decline in ATP supply and achieving a balanced homeostasis (Boutilier and St. Pierre, 2000; Hochachka and Somero, 2002; Gorr et al., 2006). In the hypoxic tolerant biological systems, response to hypoxia occurs when ATP demand and supply pathways are suppressed and consequently ATP turnover substantially reduced.

The epithelium of Carcinus posterior gills is leaky because of its high conductance. Therefore, it is a potential site for large, diffusive losses of ions through paracellular (intercellular) pathways. A considerable amount of energy is used for active uptake of salts to allow hyperosmoregulation in DSW (Onken and Siebers, 1992; Lucu and Flik, 1999; Henry et al., 2012). We have demonstrated a small decrease of conductance under severe $1.6 \mathrm{mg} \mathrm{O}_{2}$ hypoxia, when $>95 \%$ of Isc was inhibited by hypoxia. The decreased conductance of the posterior gill epithelium in DSW reduces loss of salts in Carcinus and this may lead to a lesser expense of energy, as found in fish gills (Wood et al., 2007, 2009). Such a decreased conductance might be advantageous for osmoregulation under severe hypoxia in DSW. The passive transepithelial driving forces i.e. paracellular (intercellular) pathways created by the spontaneous electrical potential across the epithelium was eliminated by Isc experiments. Therefore, our results were related to actively transported ions by epithelial cells and not to the passive movement of ions. Portions of high conductance through paracellular pathways are not detected by the short-circuit current method.

\subsection{Changes in hemolymph ionic concentrations and morphology of mitochondria by hypoxia}

Reduction of active ion Isc transport in vitro suggest that metabolic rate suppression by hypoxia can be enhanced when Carcinus live in DSW (brackish water) where $\mathrm{Na}^{+}, \mathrm{K}^{+}$- ATP-ase is considered to provide the primary driving force for hyperosmoregulation. We found that hypoxia in Carcinus induced a decrease of $\mathrm{Na}^{+}$and $\mathrm{Cl}^{-}$hemolymph concentrations. This can indicate decline in osmoregulatory capacity as suggested by Lignot et al., 2000. One explanation of the changes in hemolymph composition may be an inhibition of transcellular $\mathrm{Na}^{+}$ uptake probably driven by a $\mathrm{Na}^{+} / \mathrm{K}^{+} / 2 \mathrm{Cl}^{-}$co-transport (Riestenpatt et al., 1996). Reduced hyperosmoregulatory ability of crustaceans under hypoxia was also described by Charmantier and Soyez (1994); Legeay and Massabuau (2000).

The significant increase in the surface area of mitochondria per epithelium area unit we found in posterior gill lamella of crabs kept under hypoxic condition, was unexpected. The main area for ATP productivity is located in the inner membrane of the mitochondria facing the mitochondrial matrix. The surface area of the inner membrane forms numerous cristae providing a large surface area in comparison to the rather small overall surface of mitochondria. Since mitochondria can be regarded as a sink of oxygen, a possible explanation for the increase in the surface of mitochondria may be that the larger surface leads to increased access of oxygen and/or ADP to the mitochondria. Thus structural rearrangement of mitochondria during hypoxia may be an important adaptive mechanism increasing to some extent ATP synthesis through oxidative phosphorylation. Our suggestion of an enhanced diffusion area for oxygen from the outer membrane to the inner membrane of the mitochondria in crabs ionocyte cells was also discussed for hypoxic rat liver and heart cells mitochondria (Lund and Tomanek, 1980; Costa et al., 1988). Because of the rather low number of animals used in the morphometric approach, an effect of intraspecific variations on the results cannot completely be discounted. Future experiments are required to assess the relative effects of duration and strength of hypoxia on mitochondria surface to volume ratio.

In summary, inhibition of Isc transport activity under short-term hypoxia and by ouabain (under normoxic conditions), preferentially at the basolateral side of the isolated gill epithelium, indicate an effect on active transport generated by the $\mathrm{Na}^{+}, \mathrm{K}^{+}$- ATPase. The $\mathrm{Rb}^{+}\left(\mathrm{K}^{+}\right)$efflux $\left(\mathrm{J}_{\mathrm{B}} \rightarrow_{\mathrm{A}}\right.$ ) (mediated by basolateral uptake of $\mathrm{Rb}^{+}\left(\mathrm{K}^{+}\right)$and apical $\mathrm{K}^{+}$channel) was blocked by hypoxia and fully recovered after reoxygenation. This reduction in ${ }^{86} \mathrm{Rb}^{+}\left(\mathrm{K}^{+}\right)$fluxes reflect, at least partially, inhibition of the $\mathrm{Na}^{+}, \mathrm{K}^{+}$- ATPase mediated electrogenic transport. The inhibition of Isc by short-term hypoxia, is a metabolic response to hypoxia, which concomitantly decreases ATP consumption due to decreased ion pumping activity. Reduction of hemolymph major osmolytes $\mathrm{Na}^{+}$and $\mathrm{Cl}^{-}$in the crabs exposed to hypoxia may be the result of attenuation of osmoregulatory ability. The increase in surface area of mitochondria per $\mu \mathrm{m}^{2}$ of epithelium in crabs kept under hypoxic conditions, may be a mechanism to increase access of oxygen. We suggest that this trade-off between an increase of oxygen availability by alteration of mitochondria morphology and reduction of costs for active ion transport under hypoxia in crab posterior gills, represents an osmorespiratoy compromise enabling the animal to maintain hyperosmotic conditions at least under short- term hypoxic conditions.

Similarly to the Carcinus posterior gill (Onken and Riestenpatt, 1998) the thick ascending limb of vertebrate kidneys is also an ion absorptive epithelium. Both epithelia are equipped with an apical $\mathrm{Na}^{+}$/ $\mathrm{K}^{+} / 2 \mathrm{Cl}^{-}$cotransporter, and $\mathrm{K}^{+}$channels at both sides of the epithelia and a basolaterally located $\mathrm{Na}^{+}, \mathrm{K}^{+}$- ATPase (Greger, 1985; Gamba and Friedman, 2009). These remarkable similarities of the ionic transport mechanisms in gills with those in the thick ascending limb of the mammalian kidney, render the posterior gills to a potential model for biomedical research.

Future studies should focus on mitochondria related signaling processes under hypoxia to check their link to the energy consuming transport processes. Does expression of $\mathrm{Na}^{+}, \mathrm{K}^{+}$- ATPase $\alpha$-subunit mRNA respond to hypoxic stress?

\section{Ethic approval and consent to participate}

The research on invertebrate Carcinus maenas does not comply with national or international guidelines to be approved by ethical committee.

\section{Consent for publication}

Research was full supported by Alfred Wegener Institut Helmholtz Zentrum fuer Polar Forschung und Meeresforschung List/Sylt.

\section{Availability of data and material}

All data generated or analysed during this study are available. The authors declare no competing interests.

\section{Funding}

Alexander von Humboldt Fellowship (Č.L.):

\section{Acknowledgements}

This work and visit of Č.L. to AWI was supported by Alexander von Humboldt Foundation (grant number 1016916STP), Bonn, Germany. Thanks to Alfred Wegener Institut for Polar Research and Marine Studies from List/Sylt for laboratory facilities and kind help of Dr. Lisa Shama and Birgit Hussel. Thanks to Professors David Evans for kind suggestions and Henning Tidow, University of Hamburg for kind hospitality and help in his Lab. Thanks to Renate Kunz, Central Facility for Electron Microscopy, University of Ulm, for expert technical assistance.

\section{References}

Ahearn, G.A., Mandal, P.K., Mandal, A., 2004. Mechanisms of heavy-metal sequestration 
and detoxification in crustaceans: a review. Comp. Biochem. Physiol. B 174 439-452.

Bennett, W., Beitinger, T.L., 1995. Overview of techniques for removing oxygen from water and a description of a new oxygen depletion system. Prog. Fish Cult. 57, 84-87.

Bogdanova, A., Grenacher, B., Nikinmaa, M., Gassmann, M., 2005. Hypoxic responses of Na,K-ATPase in trout hepatocytes. J. Exp. Biol. 208, 1793-1801.

Boutilier, R.G., 2001. Mechanisms of cell survival in hypoxia and hypothermia. J. Exp. Biol. 204, 3171-3181.

Boutilier, R.G., St. Pierre, J., 2000. Surviving hypoxia without really dying. Comp. Biochem. Physiol. A Mol. Integr. Physiol. 126, 481-490.

Burnett, K.G., Burnett, L.E., 2015. Respiratory and metabolic impacts of crustacean immunity: are there implications for the insects? Integr. Comp. Biol. 55, 856-868.

Burnett, L.E., Stickle, W.B., 2001. Physiological responses to hypoxia. Coastal hypoxia: consequences for living resources and ecosystems. In: Rabalais, N.N., Taylor, R.E. (Eds.), Coastal and Estuarine Studies, vol. 58. American Geophysical Union, Washington DC, pp. 104-114 (2001).

Carra, G.E., Ibanez, J.E., Saravi, F.D., 2013. The effect of acute hypoxia on short-circuit current and epithelial resistivity in biopsies from human colon. Dig. Dis. Sci. 58, 2499-2506.

Charmantier, G., Soyez, C., 1994. Effect of molt stage and hypoxia on the osmoregulatory capacity in the shrimp Penaeus vannamei. J. Exp. Mar. Biol. Ecol. 178, 233-246.

Clarke, L.L., 2009. A guide to Ussing chamber studies of mouse intestine. Am. J. Phys. 296, G1151-G1166.

Clausen, T., 2013. Quantification of $\mathrm{Na}^{+}, \mathrm{K}^{+}$pumps and their transport rate in skeletal muscle. Functional significance. J. Gen. Physiol. 142, 327-345.

Cohen, A.N., Carlton, J.T., Fountain, M.C., 1995. Introduction, dispersal, and potential impacts of the green crab Carcinus maenas in San Francisco Bay, CA. Mar. Biol. 122, 225-237.

Compere, P., Wanson, S., Pequeux, A., Gilles, R., Goffinet, G., 1989. Ultrastructural changes in the gill epithelium of the green crab Carcinus maenas in relation to the external salinity. Tissue Cell 31, 299-318.

Costa, L.E., Boveris, O.R., Taquin, A.C., 1988. Liver and heart mitochondria in rats submitted to chronic hypobaric hypoxia. Am. J. Physiol. 255, C123-C129.

Darling, J.A., Bagley, M.J., Roman, J., Tepolt, C.K., Geller, J.B., 2008. Genetic patterns across multiple introductions of the globally invasive crab genus Carcinus. Mol. Ecol. 17, 4992-5007.

Diaz, R.J., Rosenberg, R., 2008. Spreading dead zones and consequences for marine ecosystems. Science 321, 926-928.

Fehsenfeld, S., Kiko, R., Appelhaus, Y., Towle, D.W., Zimmer, M., Melzner, F., 2011. Effects of elevated seawater $\mathrm{pCO}_{2}$ on gene expression patterns in the gill of the green crab Carcinus maenas. BMC Genomics 12, 488.

Freire, C.A., Onken, H., Mc Namara, J.C., 2008. A structure-function analysis of ion transport in crustacean gills and excretory organs. Comp. Biochem. Physiol. A Mol Integr. Physiol. 151, 272-304.

Gamba, G., Friedman, P.A., 2009. Thick ascending limb: the $\mathrm{Na},{ }^{+} \mathrm{K}^{+}{ }^{+} \mathrm{Cl}^{-}$co-transporter, NKCC2, and the calcium-sensing receptor. CaSR. Pflueg. Arch. 458, 61-76.

Gilles, R., Péqueux, A., 1985. Ion transport in Crustacean gills: physiological and ultrastructural approaches. In: Gilles, R., Gilles-Baillien, M. (Eds.), Transport Processes, Iono and Osmoregulation: Current Comparative Approaches. Springer-Verlag, Berlin, pp. 136-158.

Gorr, T.A., Gassmann, M., Wappner, P., 2006. Sensing and responding to hypoxia via HIF in model invertebrates. J. Insect Physiol. 52, 349-364.

Gray, J.S., Wu, S., Or, Y.Y., 2002. Effects of hypoxia and organic enrichment on the coastal marine environment. Mar. Ecol. Prog. Ser. 238, 249-279.

Greger, R., 1985. Ion transport mechanisms in thick ascending limb of Henle's loop of mammalian nephron. Physiol. Rev. 65, 760-797.

Henry, R.P., Garrelts, E.E., McCarty, M.M., Towle, D.W., 2002. Differential induction of branchial carbonic anhydrase and Na,K-ATPase activity in the euryhaline crab Carcinus maenas in response to low salinity exposure. J. Exp. Zool. 292, 595-602.

Henry, R.P., Gehnrich, S., Weihrauch, D., Towle, D.W., 2003. Salinity-mediated carbonic anhydrase induction in the gills of the euryhaline green crab Carcinus maenas. Comp. Biochem. Physiol. A 136, 243-258.

Henry, R.P., Lucu, Č., Onken, H., Weihrauch, D., 2012. Multiple functions of the crustacean gill: osmotic/ionic regulation, acid-base balance, ammonia excretion, and bioaccumulation of toxic metals. Front. Physiol. 3, 431.

Hochachka, P.W., Somero, G.N., 2002. Biochemical Adaptation: Mechanism and Process in Physiological Evolution. Oxford University Press New Yorkpp. 466.

Holliday, C.W., 1985. Salinity-induced changes in gill Na,K-ATPase activity in the mud fiddler crab, Uca pugnax. J. Exp. Zool. 233, 199-208.

Hug, M.J., Tuemmler, B., 2004. Intestinal current measurements to diagnose cystic fibrosis. J. Cyst. Fibros. 3, 157-158.

Kirschner, L.B., 2004. The mechanism of sodium chloride uptake in hyperregulating aquatic animals. J. Exp. Biol. 207, 1439-1452.

Larade, K., Storey, K.B., 2009. Living without oxygen: anoxia responsive gene expression and regulation. Curr. Genomics 10, 76-83.

Larsen, E.H., 2002. Hans H. Ussing - scientific work: contemporary significance and perspectives. Biochim. Biophys. Acta 1566, 2-15.

Legeay, A., Massabuau, J.C., 2000. Effect of salinity on hypoxia tolerance of resting green crab Carcinus maenas after feeding. Mar. Biol. 13, 387-396.

Li, H., Sheppard, D.N., Hug, J., 2004. Transepithelial electrical measurement with the Ussing chamber. J. Cyst. Fibros. 3, 123-126.

Lignot, J.G., Spanings-Pierrot, C., Charmantier, G., 2000. Osmoregulatory capacity as a tool in monitoring the physiological condition and the effect of stress in crustaceans. Aquaculture 191, 209-245.
Lovett, D.L., Verzi, M.P., Burgents, J.E., Tanner, C.A., Glomski, K., Lee, J.J., Towle, D.W., 2007. Expression profiles of $\mathrm{Na}^{+}, \mathrm{K}^{+}$-ATPase during acute and chronic hypo-osmotic stress in the blue crab, Callinectes sapidus. Biol. Bull. 211, 58-65.

Lucu, Č., Flik, G., 1999. $\mathrm{Na}^{+}-\mathrm{K}^{+}$-ATPase and $\mathrm{Na}^{+} / \mathrm{Ca}^{2+}$ exchange activities in gills of hyperregulating Carcinus maenas. Am. J. Phys. 276, R490-R499.

Lucu, Č., Pavičić, D., 1985. Role of seawater concentration and major ions in oxygen consumption rate of isolated gills of the shore crab Carcinus mediterraneus Csrn. Comp. Biochem. Physiol. A 112, 565-572.

Lucu, Č., Towle, D.W., 2010. Characterization of ion transport in the isolated epipodite of the lobster Homarus americanus. J. Exp. Biol. 213, 418-425.

Lund, D.D., Tomanek, R.J., 1980. The effect of chronic hypoxia on the myocardial cells of normotensive and hypertensive rats. Anat. Rec. 196, 421-430.

Marshall, W.S., Grossel, M., 2005. Ion transport, osmoregulation and acid-base balance. In: Evans, D., Claiborne, J.B. (Eds.), The Physiology of Fishes. CMC Taylor and Francis, Boca Raton, Fl, pp. 170-230.

Merz, W.A., 1967. Die Streckenmessung an gerichteten Strukturen im Mikroscop und ihr Anwendung zur Bestimmung von Oberflichen-Volumen-Relationen im Knockengewebe. Mikroskopie 22, 132-142.

Neufeld, G.J., Holliday, S.W., Prichard, J.B., 1980. Salinity adaptation of gill Na,K-ATPase in the blue crab Callinectes sapidus. J. Exp. Zool. 211, 215-224.

Nilsson, S., 1986. Control of gill blood flow. In: Nilsson, S., Holmgren, S. (Eds.), Fish Physiology; Recent Advances. Croon Helm, London, UK, pp. 86-101.

Onken, H., Riestenpatt, S., 1998. NaCl absorption across split gill lamellae of hyperregulating crabs, transport mechanisms and their regulation. Comp. Biochem. Physiol. A $119,883-893$.

Onken, H., Siebers, D., 1992. Voltage-clamp measurements on single split lamella of posterior gills of the shore crab Carcinus maenas. Mar. Biol. 114, 385-390.

Onken, H., Tresguerres, M., Luquet, C.M., 2003. Active NaCl absorption across posterior gills of hyperosmoregulating Chasmagnathus granulatus. J. Exp. Biol. 206, 1017-1023.

Pequeux, A., 1995. Osmotic regulation in crustaceans. J. Crust. Biol. 15, 1-40.

Pequeux, A., Gilles, R., Marshall, W.S., 1988. NaCl transport in gills and related structures. In: Greger, R. (Ed.), Advances in Comparative and Environmental Physiology. Springer Verlag Berlin, pp. 1-73.

Petrushanko, I.Y., Bogdanov, N.B., Lapina, L., Boldyrev, A.A., Gassmann, M., Bogdanova, A.Y., 2007. Oxygen induced regulation of Na,K-ATPase in cerebellar granule cells. J. Gen. Physiol. 130, 389-398.

Piller, S., Henry, R., Doeller, J., Kraus, D., 1985. A comparison of the gill physiology of two euryhaline crab species Callinectes sapidus and Callinectes similis: energy production, transport related enzymes and osmoregulation and function of acclimation salinity. J. Exp. Biol. 198, 349-358.

Riestenpatt, S., Onken, H., Siebers, D., 1996. Active absorption of $\mathrm{Na}^{+}$and $\mathrm{Cl}^{-}$across the gill epithelium of the shore crab Carcinus maenas: voltage-clamp and ion-flux studies. J. Exp. Biol. 199, 1545-1554.

Robertson, L.M., Hochhann, D., Bianhini, A., Matey, V., Almeda-Val, V.F., Val, A.L., Wood, C.M., 2015. Gill paracellular permeability and the osmorespiratory compromise during exercise in the hypoxia- tolerant Amazonian oscar (Astronotus ocellatus). J. Comp. Physiol. 185B, 741-754.

Saraví, F.D., Saldeña, T.A., Carrera, C.A., Ibañez, J.E., Cincunegui, L.M., Carra, G.E., 2003. Oxygen consumption and chloride secretion in rat distal colon isolated mucosa. Dig. Dis. Sci. 48, 1767-1773.

Schindele, S., Pouokam, E., Diener, M., 2016. Hypoxia/reoxygenation effects on ion transport across rat colonic epithelium. Front. Physiol. 7, 247-257 (1-10).

Siebers, D., Leweck, K., Markus, M., Winkler, A., 1982. Sodium regulation in the shore crab Carcinus maenas as related to ambient salinity. Mar. Biol. 86, 37-43.

Siebers, D., Winkler, A., Lucu, Č., Thedens, G., Weichart, D., 1985. Na-K-ATPase generates an active transport potential in the gills of hyperregulating shore crab Carcinus maenas. Mar. Biol. 87, 185-192.

Taylor, E.W., Butler, P.J., Al-Wassia, A., 1977. Some responses of the shore crab, Carcinus maenas (L.) to progressive hypoxia at different acclimation temperatures and salinities. J. Comp. Physiol. 122, 391-402.

Towle, D.W., Palmer, G., Harris, J., 1976. Role of gill $\mathrm{Na}^{+}+\mathrm{K}^{+}$-dependent ATPase in acclimation of blue crabs (Callinectes sapidus) to low salinity. J. Exp. Zool. 196, $315-322$.

Tsai, J.R., Lin, H.C., 2007. V-type $\mathrm{H}^{+}$-ATPase and $\mathrm{Na}^{+}, \mathrm{K}^{+}$-ATPase in the gills of 13 euryhaline crabs during salinity acclimation. J. Exp. Biol. 210, 620-627.

Weihrauch, D., Ziegler, A., Siebers, D., Towle, D.W., 2002. Active ammonia excretion across the gills of the green shore crab Carcinus maenas. J. Exp. Biol. 205, 2765-2775.

Weis, J.S., 2014. Physiological, Developmental and Behavioral Effects of Marine Pollution. Springer Dordrecht, Heidelberg, New York, pp. 433.

Wood, C.M., Grossel, M., 2015. Electrical aspects of the osmoregulatory TEP response to hypoxia in the euryhaline killifish (Fundulus heteroclitus) in freshwater and seawater. J. Exp. Biol. 218, 2152-2155.

Wood, C.M., Kajimura, M., Sloman, K.A., Scott, G.R., Walsh, P.J., Almeida-Val, V.M.F., Val, A.L., 2007. Rapid regulation of $\mathrm{Na}^{+}$fluxes and ammonia excretion in response to acute environmental hypoxia in the Amazonian Oscar, Astronotus ocellatus. Am. J. Phys. 292, R2048-R2058.

Wood, C.M., Iftikar, F.J., Scott, G.R., De Boeck, G., Sloman, K.A., Matey, V., ValdezDomingos, F.K., Duarte, R.M., Almedia - Val, V.M.F., Val, A., 2009. Regulation of gill transcellular permeability and renal function during acute hypoxia in the Amazon Oscar (Astronatus cellatus). New angles to the osmorespiratory compromise. J. Exp. Biol. 212, 1949-1964.

Ziegler, A., Merz, E., 1999. Membrane particle distribution in the sternal epithelia of the terrestrial isopod Porcellio scaber Latr. (Crustacea, Oniscidea) during $\mathrm{CaCO}_{3}$ deposit formation and resorption, a freeze etch analysis. J. Struct. Biol. 127, 263-278. 